\title{
THE WORK INTEGRATION SOCIAL ENTERPRISES IN GREECE
}

\author{
Ifigeneia Douvitsa
}

Hellenic Open University

Patra, Greece

\begin{abstract}
The present paper focuses on the available legal forms with work integration as their explicit purpose in the Greek legislature and outlines their main traits on the basis of the EMES (European Research Network) nine criteria of social enterprises. Their thus far implementation is also discussed, including the challenges and shortcomings that WISEs have faced in the Greek context.

The main findings of the study indicate a dominance of the cooperative form for the WISEs under the Greek context. More specifically, the legislator imposes a percentage of members coming from the target group, perceiving in that way mutuality and solidarity as rather intertwined, since the WISEs' explicit aim of work integration of the disadvantaged people is mainly achieved by joining the cooperative. Despite the supportive measures for the WISEs, the implementation of the thus far public policies has not been effective in further promoting such a model of enterprise.
\end{abstract}

KEYWORDS: Social cooperatives, WISEs, social enterprises, Greek cooperative laws.

ECONLIT DESCRIPTORS: K220, J48, J780.

Cómo citar este artículo/How to cite this article: DOUVITSA, I.: “The work integration social enterprises in Greece", CIRIEC-España, Revista Jurídica de Economía Social y Cooperativa, no 36, 2020, pp. 195-219. DOI: 10.7203/CIRIEC-JUR.36.17289. 


\section{LAS EMPRESAS SOCIALES DE INTEGRACIÓN LABORAL EN GRECIA}

\section{RESUMEN AMPLIO}

El presente documento se centra en las formas jurídicas disponibles con integración laboral como objetivo explícito en el legislador griego y describe sus principales rasgos sobre la base de la EMES (Red Europea de Investigación) nueve criterios de las empresas sociales. También se examina su aplicación hasta ahora, incluidos los desafíos y deficiencias a los que se han enfrentado las EMPRESAS, en el contexto griego.

En general, las empresas sociales de integración laboral (“WISEs") se definen como entidades económicas autónomas que se orientan principalmente a la integración profesional de las personas que se enfrentan a graves dificultades en el mercado laboral. En Grecia, el surgimiento y desarrollo de las EMPRESAS públicas pueden dividirse en tres períodos de tiempo: a) el primer período (1984-1998), durante el cual las políticas y los fondos públicos europeos incitaron a la formación de iniciativas de cooperación en fase inicial, allanando el camino para el reconocimiento jurídico de las EMPRESAS Públicas, b) el segundo período (19992010), que destaca por la institucionalización de las EMPRESAS EN EL QUE se encuentran en el sector de la salud mental y c) el tercer período (2011-2019), durante el cual las EMPRESAS se convirtieron en un vehículo para la integración de otros grupos de la población, cuya inclusión socioeconómica y laboral se vio obstaculizada por diversos factores.

En el contexto actual, el legislador introduce una serie de formas jurídicas específicas bajo una estructura cooperativa que persiguen explícitamente la integración laboral de las personas desfavorecidas. Estas formas jurídicas específicas son las cooperativas sociales de responsabilidad limitada (ar. 12 L. 2716/1999), las cooperativas agrícolas de mujeres (L. 4384/2016), las empresas de cooperación social de integración de grupos vulnerables y de grupos especiales (L. 4430/2016) y las cooperativas sociales de integración (ar. 143 L. 4600/2019).

Bajo este prisma, el documento se centra en las formas jurídicas anteriores con la integración del trabajo como objetivo explícito y describe sus principales rasgos sobre la base de la EMES (Red Europea de Investigación) nueve criterios de las empresas sociales, que son una actividad continua de producción de bienes y/o servicios de venta, un nivel significativo de riesgo económico y una cantidad mínima de trabajo remunerado, un objetivo explícito para beneficiar a la comunidad, una iniciativa lanzada por un grupo de ciudadanos u organizaciones de la sociedad civil y una distribución limitada de beneficios, un alto grado de autonomía, un poder de decisión no basado en la propiedad de capital y un carácter participativo. 
Más concretamente, se observó que la mayoría de los indicadores EMES que definen una empresa social se reflejan en las disposiciones sobre las formas jurídicas en estudio y que esas disposiciones no difieren significativamente entre sí. Sin embargo, este no fue el caso de los indicadores de la limitación de la distribución de beneficios y del carácter participativo, en los que las formas jurídicas en estudio presentaban divergencias, a partir de una distribución de beneficios sin limitaciones a una limitación sin fines de lucro y de una estructura obligatoria de una sola parte interesada a una estructura de múltiples partes interesadas de los miembros y miembros del consejo de administración.

En cuanto a la aplicación y los desafíos a los que se enfrentan las EMPRESAS WIS, se observan los siguientes. En el caso SCLL, aunque el objetivo inicial de establecer 58 SCLL (uno en cada sector de salud mental) no se realizó en tal medida (Adán 2014, 12), el número del SCLL registrado hasta ahora en el registro de la economía social -que no es obligatorio para adquirir una personalidad jurídica- ha aumentado a 27 (Registro de Economía Social y Solidaria). Sobre la base de investigaciones anteriores, su capacidad para alcanzar su objetivo prioritario, mediante la creación de empleos bien remunerados a tiempo completo para el grupo objetivo ha estado en cuestión (Adam 2014, 19-25). En algunos casos, se han observado discrepancias entre el grupo objetivo y los profesionales con respecto a las condiciones de trabajo asociadas con el pago, el contrato de trabajo formal y las horas de trabajo (Adam 2014, 19-25). Por otro lado, varios SCLL han podido firmar contratos públicos con las autoridades públicas para la prestación de servicios en ámbitos como la restauración, los servicios de limpieza o la jardinería. Además, doce años después de la promulgación del ar. 12 L. 2716/199 en el SCLL, la Federación Panhelénica de Uniones DE LA SCLL fue fundada por 14 SCLL. La federación ha estado activa desde entonces en: a) promover los intereses del SCLL, b) representarlos al Estado griego, a los organismos nacionales e internacionales y a, a, c) arrojar luz sobre cuestiones relacionadas con el SCLL y proporcionar información a sus miembros-SCLL, d) cooperar con el Estado griego y la UE y esforzarse por abordar los problemas a los que se enfrenta el SCLL.

En lo que respecta a la SCE, sólo se han formado unos pocos SCE de integración, que se trata principalmente de ECE de integración de grupos vulnerables, lo que indica que no se ha aplicado la forma jurídica anterior para la integración de los solicitantes de empleo capaces que se enfrentan a graves problemas para integrarse (re)integrados en el mercado de trabajo. Una observación general para la mayoría de las SCE es que tienden a tener una actividad económica limitada, dependiendo en gran medida del trabajo voluntario y con una pequeña contribución a la creación de vacantes bien pagadas a tiempo completo (Douvitsa 2016, 13-14; Secretario Especial de Economía Social y Solidaria 2018, 102-110). La falta de inversión social y de sistemas financieros adecuados adaptados a sus necesidades se suele mencionar como algunos de los desafíos a los que se enfrentan. Además, el L. 4430/2016 se inclina por la sobrerregulación 
de los actores de la SSE, en la que se incluyen las RSE de integración y disuadiendo así a las partes interesadas de elegirla como forma jurídica para su iniciativa (Adam 2018, 239).

En cuanto a las cooperativas agrícolas de mujeres, se observó que durante los años de crisis $1 / 3$ de ellas quedaron inactivas. Este último llevó al Ministerio de Agricultura a emprender una investigación sobre los desafíos y deficiencias a los que se enfrentaban. Sobre la base de los resultados del informe del Ministerio, estas cooperativas son empresas muy pequeñas basadas en mano de obra manual. Producen principalmente en cantidades bajas, que se venden localmente. Como resultado, algunos de los problemas más importantes a los que se enfrentan son: los altos costos de producción, su incapacidad para aumentar las cantidades de productos, la dificultad para acceder a los mercados nacionales e internacionales y en invertir en infraestructura y nuevas tecnologías. Además, también se observó la falta de un perfil competitivo de sus productos en los mercados y la ausencia de una certificación de producto (por ejemplo, ISO). Otra cuestión que también se puso de relieve fue la ausencia de asociaciones formadoras y de un órgano de coordinación que representara sus intereses (Tsiomidou 2016, 2-13).

Por último, el SCI es una forma jurídica recientemente prescrita por la ley y, por lo tanto, se basa en los datos del Departamento de Tratamiento de las Adicciones del Ministerio de Salud, no se ha establecido ningún registro de que se haya establecido el LIC, hasta ahora.

Además, la contratación pública, la excepción fiscal y la utilización de bienes públicos inmuebles o muebles se encuentran entre las medidas fundamentales de apoyo prescritas por la ley para las formas jurídicas anteriores para las empresas de servicios wi-fis. A pesar de estas medidas, las ESS en estudio representan aproximadamente 188 de los 1.638 actores de la EES $(10,6 \%)$ y se enfrentan a una serie de desafíos asociados con su capacidad para crear empleos a tiempo completo y bien remunerados para el grupo objetivo, la dificultad para acceder a los mercados nacionales e internacionales y en la inversión en infraestructura y nuevas tecnologías, entre otros.

Para concluir, se observa un dominio de la forma cooperativa para las EMPRESAS WISEs en el contexto griego. El legislador impone un porcentaje de miembros procedentes del grupo objetivo, percibiendo de esa manera la mutualidad y la solidaridad como más bien entrelazados, ya que el objetivo explícito de las WISEs de integración laboral de las personas desfavorecidas se logra principalmente uniéndose a la cooperativa. Aunque, el legislador prescribe medidas de apoyo para las EMPRESAS, las políticas públicas hasta ahora no han logrado seguir promoviendo ese modelo de empresa, que posee un porcentaje marginal del sector de la economía social y solidaria.

PALABRAS CLAVE: Cooperativas sociales, empresas sociales de integración laboral ("WISEs"), empresas sociales, legislación cooperativa griega. 


\section{SUMMARY}

1. The emergence and development of work integration social enterprises in Greece. 2. The current legal framework. i) Social Cooperatives of Limited Liability (ar. 12 L. 2716/1999). ii) Women's Agricultural Cooperatives (L. 4384/2016). iii) Social Cooperative Enterprises (SCE). iv) Social Cooperatives of inclusion (ar. 143 L. 4600/2019). 3. Assessment of the legal context based on the EMES criteria. i) Economic and entrepreneurial dimensions of social enterprise. ii) Social dimensions of social enterprise. iii) Participatory governance of social enterprise. 4. Supportive measures for the WISEs development. 5. The thus far implementation and challenges. 6 . Concluding remarks. Bibliography.

\section{The emergence and development of work integration social enterprises in Greece}

WISEs are defined as economic entities which are autonomous and mainly pursue the professional integration of people that face serious difficulties in the labour market. Such integration may occur either through the WISE itself and its productive activity or by offering training to the target group and enable it to be hired in a mainstream enterprise (Davister, Defourny and Gregoir 2004, 3).

As WISEs are particular types of social enterprises, the nine criteria of the EMES (European Research Network) which are used to define social enterprises may also be applicable in their case. In particular, the EMES has identified three indicators for the different dimensions of social enterprises. Specifically, the economic and entrepreneurial dimensions of a social enterprise emerge from a continuous activity producing goods and/or selling services, a significant level of economic risk and a minimum amount of paid work (Defourny 2001, 16-17; Defourny and Nyssens 2012, 12-13). Moreover, the social dimensions of a social enterprise are closely linked with an explicit aim to benefit the community, an initiative launched by a group of citizens or civil society organisations and a limited profit distribution (Defourny, 2001, 17; Defourny and Nyssens, 2012, 14). Furthermore, the social enterprise's participatory governance arises from a high degree of autonomy, a decision-making power not based on capital ownership and a participatory nature, which involves various parties affected by the activity (Defourny 2001, 17-18; Defourny and Nyssens 2012, $14-15)$ 
In a number of countries, such as Italy, Portugal, France and Spain there have been some recent legal developments recognizing and supporting such enterprises (Davister, Defourny and Gregoir 2004, 24). Depending on the national legislation, WISEs are subject to their own legal framework, whereas in other cases they do not enjoy a complete and specific legal recognition, but operate under various legal forms (Spear and Bidet, 2005, 203-204).

In Greece the emergence and development of WISEs may be divided into three time periods: a) the first period (1984-1998), during which the European public policies and funds incited the formation of early-stage cooperative initiatives, paving the way for the WISEs legal recognition, b) the second period (1999-2010), which is notable for the WISEs institutionalization in the mental health sector and c) the third period (2011-2019), during which the WISEs became a vehicle for the integration of other groups of the population, the socio-economic and work inclusion of which was hindered by various factors.

The emergence of WISEs in Greece was the product of a long process of reforming the mental health care system in Greece, in terms of improving the conditions of the mental health care inside the hospitals and clinics, while putting under question the effectiveness of mental health asylums and at the same time strive for ways for the patients' emancipation, social inclusion and work rehabilitation (Adam 2014, 9; Stefanakis 2010, 26). When the poor conditions of the mental health system of Greece were exposed by the international press, the country was pressured by the European Economic Community ("EEC" hereafter), in which it was recently adhered, to undertake immediate action in order to improve its psychiatric care system (Adam 2014, 9; Stefanakis 2010, 26). To this aim, the EEC based on ar. 1 of the Regulation $815 / 1984$ provided an exceptional financial support for the education of the mental health professionals and staff, for work integration projects and for the decentralization of mental health services.

A number of informal cooperative therapeutic units were formed as a result of the above and of other European funding schemes and national programs (e.g. Leros I\&II, Psychargos) (Adam 2014, 11). These early stage cooperative units strived to address the wide phenomenon of the black labour of the mental health patients, while focusing on the social and work integration of the ex- residents of mental health clinics (Stefanakis 26-27). In order for these cooperative therapeutic units to become a true version of a cooperative enterprise and further develop independently from the mental health hospitals, an appropriate legal framework had to be enacted (Stefanakis 2010, 27-28). To this end, Law 2716/1999 was promulgated, which in its ar. 12 prescribed for the very first WISEs under the form of social cooperatives of limited liability ("SCLL" hereafter). With the above provisions, the modus operandi 
of the SCLL was specified and the issues that were previously raised with the cooperative therapeutic units regarding the fiscal treatment, social insurance and social protection benefits of the mentally ill were tackled in the legal text (Adam 2014, 11).

From 1999 until the 2008 crisis, the model of WISEs was used for the integration of individuals with mental health problems, without any attempt by the legislature to introduce new types of WISEs or expand the target group of the existing ones to other disadvantaged groups of the population that faced social and work exclusion.

However, with the 2008 crisis outburst, the imposed austerity measures led to welfare cut outs, while the groups of the population that faced social-economic exclusion grew, alongside its needs (Papadopoulos and Roumpakis 2012). During the Greek "Indignados" (Anti-austerity) movement various civil society actors came together, some of which formed informal networks striving to cover the said unmet needs (e.g. by forming social solidarity clinics and pharmacies). Under these conditions, L. 4019/2011 was passed prescribing for the SCEs of integration, the social services' SCEs and the SCEs with a collective and productive purpose. The aforementioned law was substituted by L. 4430/2016. L. 4430/2016 (drafted by the Ministry of Labor) aimed- among others- to facilitate the formation of smallsized producer/worker initiatives under a co-operative structure during the post-crisis years of high unemployment and small and medium size businesses shut down. In relation to WISEs, the recent law introduced two types under the form of SCEs of integration of vulnerable and special groups ${ }^{1}$. In addition, a new WISE type has recently been enacted by ar. 143 L. 4600/2019. The latter provision prescribes for the establishment of social cooperatives of integration, which aim at the integration of addicts or ex-addicts.

\section{The current legal framework}

WISEs in Greece may be established under various legal forms. However, the legislator introduces a number of specific legal forms under a cooperative structure that explicitly pursue the work integration of disadvantaged people, in which the present paper shall focus. To this end, a dominance of the cooperative form for the WISEs is noted under the Greek context. These specific legal forms are the following:

1. The present paper focuses on the main legal forms that have as their exclicit purpose the work integration of disadvantaged people. The social cooperative enterprises of collective and social benefit that undertake sustainable development-oriented activities or/provide social services are not analyzed, since they have a rather broader purpose than the social cooperative enterprises of integration. 


\section{i) Social Cooperatives of Limited Liability (ar. 12 L. 2716/1999)}

L. 2716/1999 in its article 12 introduced the very first social enterprises of integration under the legal form of SCLL. This new type of cooperative is subject to ar. 12 L. 2716/1999 with its 19 paragraphs and to L. 1667/1986 on civil cooperatives which is applied complimentarily.

In particular, ar. 12.1 L. 2716/1999 stipulates that SCLL aim at the socio-economic integration and work inclusion of individuals with mental health problems. Such cooperatives have a dual function. On the one hand, they operate as an enterprise, they acquire a commercial status, which enables them to be involved in commercial activities, but they also function as a mental health unit. In this way, the legislator aspires to encourage the formation of a particular type of cooperative, in which the target group (which are the mentally ill) can both work and receive treatment. In this legal form, working and getting treatment seem to be intertwined and mutually reinforcing.

Pursuant to ar. 12.2 L. 2716/1999, SCLL can undertake any type of economic activity and have their headquarters at the municipality, where their board of director is located. However, the law stipulates that only one SCLL can be established in each regional unit and one in each mental sector of Attica and Thessaloniki. The reason behind such limitation is relevant to the way the public health system is organized in each region, since SCLL are considered to be mental health units that belong to the mental health sectors of the country. On the other hand, SCLL can establish and maintain selling shops and branches anywhere they decide.

For the SCLL's establishment there is no minimum initial capital required by law. With regard to membership, an SCLL may be formulated by at least 15 members. The founding members shall sign the statute and submit it to the local courts to examine whether it is in accordance with the legislation. Prior to that, the Minister of Health and Welfare issues a license of expediency, examining the statute, the capacity of the existing mental health units and the development opportunities of the particular area, where the SCLL shall be located, taking also into account the opinion of the mental health sector (Explanatory memorandum 1999, 14).

SCLL membership is subject to ar. $12.4 \mathrm{~L}$. 2716/1999 which prescribes for its multi-stakeholder structure. Based on the latter, there are three categories of membership:

a) the first category which consists of individuals with mental health issues which irrespective of their residence and stage of illness are in need of recovery based on the opinion of a competent sectorial committee of mental health. Such indi- 
viduals can be adults or adolescents but no less than 15 years old, even if they have no legal capacity by way of derogation from the civil code and cooperative legislation. At least 35\% of the total number of SCLL members are required to originates from category $\mathrm{A}^{2}$,

b) the second category consists of individuals which are adults and work at the mental health sector. According to ar.12.4 L. 2716/1999 civil servants, psychiatrics, psychologists of the National Health System may also join the cooperative. Up to $45 \%$ of the total number of SCLL members may originate from category B,

c) the third category consists of individuals and legal entities of private or public law (e.g. hospitals of the National Health System) that can also participate as long as the statute allows so. Up to $20 \%$ of the total number of SCLL members may originate from category $\mathrm{C}$.

The law neither encourages nor forces a renewal of member participation of the above categories. Therefore, the conditions under which such renewal may take place are left to the members to decide accordingly based on the cooperative's activities and needs.

The law goes on and prohibits members of an SCLL to join another SCLL of the same or similar purpose which headquarters are at the same mental health sector.

Based on the above provision a multi-stakeholder membership basis is mandatory for the SCLL of two or even three member categories if the statute says so. Therefore, an SCLL cannot be established without any members from category A (mentally ill) and category B (mental health professionals), which reflects the realization of its dual function: as an enterprise and a mental health unit.

Regarding the rights and obligations of each member category, no particular provisions differentiate them apart from ar. 12.5 L. 2716/1999 on their occupation status. Namely, the members of category A (mentally ill) may offer their services to the cooperative and get remunerated, without losing any welfare benefits. The members of category B can also offer full time or part time their services at the cooperative without however being remunerated by the cooperative. The cooperative is only obligated to cover their expenditure related to their work at the cooperative. More specifically, mental health professionals that work in a mental health unit of the mental

2. There is no available data that may shed some light on the criteria under which the members of category a are chosen to become a member of an SCLL. Nevertheless, in a research on 15 SCL it was found that $67 \%$ of such members had not graduated from high school and $65 \%$ of such members had less than three years working experience. However, according to Adam, we cannot generalize such remarks, since in a number of SCLL there is a lack of data regarding the social, economic and professional profile of members from category a. (Adam, 2012, 243). 
health sector, which collaborates with the cooperative, can also choose to work in parallel or exclusively at the cooperative. The cooperative can also hire workers that have not joined the SCLL as members. Although the latter do not enjoy any voting rights at the general assembly, they can nevertheless attend and express their opinion according to the statute's provisions (ar. 12.16 L. 2716/1999).

Concerning the capital contributions to the cooperative, the law in ar. $12.7 \mathrm{~L}$. $2716 / 1999$ stipulates that each member acquires one mandatory cooperative share and up to 5 additional, non-voting shares. Such limitation is non applicable to legal persons of public law or non-profit legal persons of private law that may acquire an unlimited number of additional non voting shares. In case members leave the cooperative, then the mandatory share along with the non-voting shares are returned within three months from the end of the financial year (ar. 12.6 L. 2716/1999). The manner under which the cooperative addresses capital fluctuation due to member fluctuation is left to the members to decide accordingly.

Irrespective of the capital that members contribute to the cooperative, each member holds one vote to the general assembly, in which all members participate. Apart from the general assembly, the law prescribes for the formation of a board of directors and a supervisory council. The latter is not mandatory for SCLL with less than 20 members. The multi-stakeholder structure is also reflected in the composition of the board of directors. In particular, the board of directors consists of seven members, two of which are members of category A (mentally ill) under the condition that they are not subject to a full custodian guardianship and the rest are members of category B and C. Although the members of category A can be elected as members of the board of directors, they cannot serve as presidents, secretaries or treasurers. Contrary to the provisions of the board of directors, the members of category A cannot be elected as members of the supervisory board due to the demanding duties and high degree of responsibility, which they would be exposed to by joining such body (Explanatory memorandum 1999, 17).

In the SCLL case the legislator refers only to profits (including thus surplus) which are distributed (ar. 12.12 L. 2716/1999): a) to the legal reserve (at least 1/20 of the profits), when the amount of the legal reserve reaches the total value of the mandatory cooperative shares, then such deduction is no longer mandatory, b) to the formation of other reserves as well, upon a decision of the general assembly, c) to the members. In case the statute does not contain any opposite provisions, then 50\% of the profits shall be allocated to the members in proportion to their cooperatives shares and $50 \%$ of the profits shall be allocated to the members in proportion to their transactions with the cooperative. 
In case of SCLL liquidation the remainder capital may be distributed to the members. However, the special reserve that is formulated by new members contributions in proportion to the cooperative's assets is indivisible and in case of SCLL dissolution, it cannot be distributed to the members but be given for relevant goals, although the law does not further specify which these are.

L.2716/1999 also introduces provisions for the vertical integration of SCLL. Based on ar.12.15 L. 2716/1999 at least 5 SCLL can form a union for the coordination and promotion of their activities. The unions and the first-tier SCLL can also form a Panhellenic federation of unions of SCLL aiming at the general representation and coordination of the activities of social economic and work integration of persons with mental health problems.

\section{ii) Women's Agricultural Cooperatives (L. 4384/2016)}

The agricultural cooperative movement has had a strong presence under the Greek context. Usually such cooperatives have been male-dominated with a low participation of rural women as members of the cooperative, as well as in the administration of the enterprise. In order to enable the empowerment of women of the rural areas of Greece, provide them with adequate skills and overall facilitate their economic, social and professional integration, the legislator introduces a legal form of WISEs specifically addressed to rural women (Tsiomidou 2016, 2-13).

In particular, L. 4384/2016 introduces provisions on agricultural cooperatives and in its ar. 2 it introduces specific provisions for the women's agricultural cooperatives. The specific provisions on the women's agricultural cooperatives permit a lower membership number and a simplified structure of governance and thus diverging from the applicable rules on the agricultural cooperatives. For all the other matters regarding their establishment, capital formation, function and operation, the general provisions of L. 4384/2016 on agricultural cooperatives are applicable.

Specifically, in its ar. 2.1 L. 4384/2016 the law lays down that at least 5 members may establish a women's agricultural cooperative. In such cooperative the membership consists exclusively of women. Therefore, no men or legal persons may join the cooperative. As with all agricultural cooperatives, ar. 4.1 L. 4384/2016 is applicable which specifies the process of their establishment. In particular, the statute of the cooperative after being signed by the required number of founding members is submitted before the local court, where the cooperative shall have its headquarters. The judge shall dictate or reject the registration of the statute at the registration book of agricultural cooperatives. Upon registration of its statute, the cooperative shall ac- 
quire legal personality and a commercial status. Concerning the capital contribution of the members, ar. 9 L. 4384/2016 dictates that each member acquires one mandatory share and additional non-voting shares, if the statute permits so. Irrespective of the capital contribution of the members to the cooperative, each member holds one vote to the general assembly. The general assembly elects the members of the board of directors and of the supervisory council. Pursuant to ar. 2.2 L. 4384/2016, in the case of the women's agricultural cooperatives with less than 10 members, instead of a board of directors, the management of the cooperative may be exercised either by all members or by a single director that shall be a cooperator herself and elected by the members of the cooperative. The formation of a supervisory council is also non mandatory for all agricultural cooperatives (including women's) with less than 30 members (ar. 11 L. 4384/2016). One interesting point raised by L. 4384/2016 is the members' obligation to submit at least $80 \%$ of their total production to the cooperative and purchase supplies by it and if not, it constitutes grounds for member exclusion (ar. 8.3, 8.5 L. 4384/2016).

With regard to surplus/profit distribution ar. 23 L. 4384/2016 is applicable for all agricultural cooperatives, including the women's agricultural cooperatives. In particular, the surplus is defined as the positive economic result generated from the transactions of the cooperative with its members. Following that, the surplus is allocated: a) to the cooperators with additional non-voting shares, if the by-laws dictate, b) to a mandatory reserve (at least $10 \%$ of the surplus), c) to the members in proportion to their transactions with the cooperative, d) for the cooperative's development, e) for the education/training of its members (at least $2 \%$ of the surplus).

On the other hand, the profits are defined as the positive economic results generated by the transactions of the cooperative with non-members and they are distributed: a) to the mandatory reserve, b) for the development of the community upon decision of the general assembly.

Based on the above, the women's agricultural cooperatives are single stakeholder WISEs that aim at the work integration of their members, which shall be achieved by joining the cooperative and selling the majority of their produce to it.

\section{iii) Social Cooperative Enterprises (SCE)}

The recent law 4430/2016 on social and solidarity economy introduces two legal forms which exclusively pursue the work integration of disadvantaged people. These are the following: a) the social cooperative enterprises of the inclusion of vulnerable groups, b) the social cooperative enterprises of the inclusion of specific groups. 
The social cooperative enterprises ("SCE" hereafter) of the inclusion of vulnerable groups aim at the socio-economic inclusion of persons that originate from the vulnerable groups. Such groups are defined by law as those whose integration is hindered due to physical, mental reasons or due to delinquent behavior (e.g. people with disabilities, people with addiction problems, prisoners / ex-prisoners). At least 30\% of the total number of members and workers of the SCE are required to originate from the above group.

The SCE of the inclusion of special groups aim at the socio-economic inclusion of people that originate from the special groups. Such groups are defined by law as those whose integration is hindered due to economic, social and cultural reasons (e.g. sex-trafficking victims, victims of domestic violence, homeless, people living under poverty conditions, refugees and asylum seekers while their request is pending). At least $50 \%$ of the total number of members and workers of the SCE are required to originate from the above group. The criteria under which potential members from the target group are chosen are left to the cooperative to decide accordingly ${ }^{3}$.

The explanatory report that accompanies L. 4430/2016 does not offer any particular justification of the necessity of introducing two different types of SCEs of integration, instead of one that could have had as its purpose the integration of both vulnerable and special groups of the population. One possible reason may be found in the way the law differentiates these two groups: the vulnerable groups of the population are hindered due to physical and mental reasons, whereas the special groups are hindered due to economic, cultural, social or political reasons. Therefore, one may argue that due to the different reasons that hinder their integration, each group may have different needs of education, training and support that may be better addressed when the target group has a certain degree of uniformity.

Based on ar. 15.2 L. 4430/2016, an SCE of integration of vulnerable and special groups may be established by at least seven persons. The participation of legal persons in SCE is subject to a number limit: legal persons may be up to $1 / 3$ of the total number of members. Legal persons of public law or private law after approval of their public entity that supervises them can join an SCE of integration. All members acquire one mandatory share, which cannot be less than 100 euros and up to 5 additional non-voting shares. Irrespective of their capital contributions all members hold one vote to the general assembly. Apart from the latter the SCE also has a board of directors. The SCE can also hire workers which are non-members, but only up to $40 \%$ of its total number of workers. The above percentage may be increased up to

3. There is no available data that may shed some light on the criteria under which the members of category a are chosen to become a member of an SCE. 
$50 \%$ to fill-in the seasonal needs of the enterprise and upon decision of the Social and Solidarity Economy Register Department, but only for a 6-month period.

The positive economic result is allocated as follows: a) at least $5 \%$ to the legal reserve, b) up to $35 \%$ to the workers of the SCE as a bonus, unless the general assembly with a $2 / 3$ majority decides to allocate it partly or fully to the creation of vacancies and reinvest it to the cooperative, $c$ ) the rest is allocated to the creation of vacancies and is re-invested to the cooperative.

In case members leave the cooperative, then the mandatory share along with the non-voting shares are returned within three months from the end of the financial year the manner under which the cooperative addresses capital fluctuation due to member fluctuation is left to the members to decide accordingly.

The remainder capital after liquidation is prohibited from being distributed to the members and is allocated to the Social Economy Fund. However, until the fund is established, the remainder capital may be distributed to the members.

Under this legal form, integration of the target group is mainly conceived through joining or/and working for the cooperative, but the legislator perceives it as a temporary process, during which the SCE shall offer the target group work experience for their skill improvement and increase their employability in the labour market. Although the law prescribes for a renewal of the target group, the conditions under which such renewal may take place are left to the members to decide accordingly based on the cooperative's activities and needs. According to ar. 14.2 aa L. 4430/2016, the specific timeframe shall be further specified in the statute of the SCE. Apart from the participation of the target groups, other types of members are not prohibited from joining the cooperative. Nevertheless, a multi-stakeholder structure is neither encouraged nor imposed in the SCE case. The fact that profit distribution to non worker members is prohibited received criticism according to which a multi-stakeholder structure is not promoted, since there are no financial motives for non workers to join an SCE (Douvitsa 2016, 7).

The integration of people with mental illnesses may be pursued by both SCLL as well as SCEs of integration of vulnerable groups. The two different legal forms have a number of differences, the most important of which are related to the required by law minimum number of members, the membership structure and the distribution of profits. Specifically, an SCE may be established with only 7 persons, whereas an SCLL requires at least 15 persons. Furthermore, in the SCLL a multi-stakeholder structure is mandatory by law, whereas this is not the case for the SCEs. Also, profits may be distributed only to the workers-members and workers non-members in the SCEs. On the contrary, for the SCLL, the law is flexible permitting the bylaws to introduce specific provisions on the matter. Therefore, based on the above, the SCEs 
are an adequate legal form for initiatives with a lower membership, which accept a profit distribution constraint on members that do not work for the cooperative. Regarding which legal form is more broadly used, we cannot draw safe conclusions due to the lack of available data on the SCEs that focus on the integration of people with mental illnesses.

\section{iv) Social Cooperatives of inclusion (ar. 143 L. 4600/2019)}

L. 4600/2019 in its article 143 introduced the most recent WISE under the legal form of social cooperatives of integration ("SCI” hereafter). All matters that are not addressed in L. 4600/2019 are subject to ar. 12 L. 2716/1999 on SCLL and to L. 1667/1986 on civil cooperatives which are applied complimentarily. In fact, the differences between the SCLL and SCI are rather few, which renders questionable the necessity of enacting a new law, instead of expanding the target group of ar. 12 L. 2716/1999 (: people with mental health problems) to other disadvantaged people, such as addicts and ex-addicts.

In particular, ar. 143.1 L. 4600/2019 stipulates that SCI aim at the socio-economic integration and work inclusion of individuals with substance abuse problems under the following conditions: a) that these individuals attend programs of social re-inclusion by a list of organizations of ar. 51 L. 4139/2013 with a focus on treating people with substance abuse problems (e.g. the Psychiatric Hospital of Athens, the Organization against Drugs, the Addiction Treatment Centre) b) or that these individuals have already completed such programs and received certification.

Such cooperatives have a dual function. On the one hand, they operate as an enterprise, they acquire a commercial status, which enables them to be involved in commercial activities, but they also function as a unit of social inclusion. These types of cooperatives are perceived as a continuation of the educational programs that are provided by the organizations of ar. 51 L. 4139/2013 with a focus on treating people with substance abuse problems (Explanatory report 2019, 36). In this way, the legislator aspired to encourage the formation of a particular type of cooperative, in which the target group (which are substance addicts or ex addicts) can both work and receive support.

As in the SCLL case, the SCI according to ar. 143.4 L. 4600/2019 can undertake any type of economic activity and they have their headquarters at the municipality, where their board of directors is located. However, the law stipulates that only one SCI can be established in each regional unit, apart from Thessaloniki's, where up to 3 SCI may lawfully be established (ar. 143.7 L. 4600/2019). Nevertheless, the SCI can open and maintain selling shops and branches anywhere they decide. 
For the SCI's establishment there is no minimum initial capital required by law. With regard to membership, an SCI may be formulated by at least 15 members. The founding members shall sign the statute and submit it to the local courts to examine whether it is in accordance with the legislation. The Minister of Health shall also issue a license of expediency, after receiving also the recommendation of the competent organizations of ar. 51 L.4139/2013 (ar. 143.9 L. 4600/2019).

SCLL membership is subject to ar. $143.10 \mathrm{~L}$. 4600/2019 which prescribes for its multi-stakeholder structure. Based on the latter, there are three categories of membership:

a) the category $\mathrm{A}$, which consists of individuals which are addicts or ex addicts, as described in ar. 143.1 L. 4600/2019, at least 18 years of age. Relapsing, which is to be verified by the competent organizations, holds reason for the member's expulsion. At least $35 \%$ of the total number of SCI members are required to originate from category A,

b) the category $\mathrm{B}$ consists of individuals which are adults and work at the organizations of ar. 51 L. 4139/2013 that focus on treating people with substance abuse problems. According to ar. $143.10 \mathrm{~b} \mathrm{L.} 4600 / 2019$ up to $45 \%$ of the total number of SCI members may originate from category B,

c) the category $\mathrm{C}$ consists of individuals and legal entities of private or public law (e.g. local authorities, hospitals and clinics) that can also participate as long as the statute allows so. Up to $20 \%$ of the total number of SCI members may originate from category $\mathrm{C}$.

The law goes on and prohibits members of an SCI from joining another cooperative of the same or similar purpose and its headquarters at the same regional unit (ar. 143.10 L. 4600/2019).

Based on the above provision a multi-stakeholder membership basis is mandatory for the SCI of two or even three member categories if the statute says so. Therefore, an SCI cannot be established without any members from category A (addicts, ex-addicts) and category B (employees to the above organizations), as it has also been stated for the SCLL.

For all the rest issues on the rights and obligations of each member category, the capital contributions to the cooperative, the one-member-one vote rule, the governance bodies, the profit-distribution, the liquidation and the vertical integration the relevant provisions of ar. 12 L. 2716/1999 on SCLL apply in the SCI. 


\section{Assessment of the legal context based on the EMES criteria}

Having outlined the key traits attributed to the WISEs by the Greek legislator, they will be further assessed based on the EMES indicators for the economic and social dimensions of social enterprises, in order to investigate whether such indicators are reflected in the legal text and if so, to what degree. Although such indicators were not meant to work as prescriptive criteria (Defourny 2013,2), they are used to facilitate a comparison between the various different legal forms of WISEs and to outline the variations among them.

\section{i) Economic and entrepreneurial dimensions of social enterprise}

A continuous activity producing goods and/or selling services

All the legal forms under study for WISEs are acknowledged with the legal personality of a cooperative. When WISEs take the form of a cooperative, they are granted by law the ability to carry on commercial acts, selling or providing products and services in the markets.

\section{A significant level of economic risk}

The members of the SCLL, the women's agricultural cooperatives, the SCE and the SCI shall assume an economic risk, which is limited and in proportion to their shares' rate.

\section{A minimum amount of paid work}

The laws under study on WISEs do not impose a minimum amount of paid work as a prerequisite for their lawful function. Nevertheless, SCE and SCLL (as ope legis SSE actors) and women's agricultural cooperatives and SCI (if acknowledged as SSE actors) are subject to ar. 3.4 L. 4430/2016. According to the latter, all SSE actors with a high annual turnover are obligated to allocate a $25 \%$ of their annual turnover for salaries, implying therefore that a minimum amount of paid work is required by law.

\section{ii) Social dimensions of social enterprise}

An explicit aim to benefit the community

In the Greek framework, the aim of the legal forms under study seem to reflect their social dimension, since their explicit purpose specified by law is the integration 
of disadvantaged groups of the population. In the legal forms under study there is a minimum percentage of members (or the total number of members in the case of women's agricultural cooperatives) that comes from the target group. The integration shall mainly occur by joining the cooperative, since these cooperatives can not be established without any members from the target group. The SCE are the only legal form where integration is stipulated by law as a temporary process and the specific timeframe shall be further specified in their statutes. For the rest, the law remains silent which permits WISEs in becoming worker cooperatives pursuing eventually the creation and maintenance of permanent vacancies for their target group. This hypothesis is reaffirmed by research findings on SCLL, according to which the highest priority for SCLL is to create permanent jobs (Adam 2014, 16).

\section{An initiative launched by a group of citizens or civil society organisations}

The cooperative structure permits the interested parties to freely establish any type of the above legal forms for WISEs.

\section{A limited profit distribution}

Regarding the limited profit distribution criterion, limitations are imposed by law in the case of SCE and women's agricultural cooperatives, which reflects the sociality of their scope. Conversely, SCLL and SCI may allocate their profits to their members, except for a percentage allocated to the legal reserve.

\section{iii) Participatory governance of social enterprise}

\section{A high degree of autonomy}

The autonomy of the legal forms under study originates from their cooperative structure, since they are formed and managed by their members, as it is the case for every cooperative. Additionally, the legislator introduces in some cases further measures to prevent the WISEs' dependence, especially from the public sector. More specifically, in the SCLL case, such measures are the following: a) only up to $20 \%$ of members may come from category c (in which public law entities and municipalities are included), b) only up to 5 out of 7 members of the board of directors may come from category b and c, c) each member has one vote irrespective of the capital that it contributes. In practice, it has been noted that there was no representative from category $\mathrm{c}$ in the board of directors of 7 out of 15 SCLL and in the supervisory board 8 out of 15 SCLL. The latter seems to indicate that public law entities are not inclined 
to actively participate in the SCLL management (Adam, 2012, 168). On the other hand, the fact that public law entities may acquire an unlimited number of voluntary shares, which are returned in case of them exiting the cooperative, may compromise the SCLL independence. Nevertheless, in practice, it has been noted that public law entities that join a SCLL as its members tend to acquire only a few shares (Douvitsa, 2020, 15).

\section{A decision-making power not based on capital ownership}

Decisions are made under the principle "one member-one vote", without any exceptions for all the studied legal forms.

\section{A participatory nature, which involves various parties affected by the activity}

With regard to the participatory nature of the WISEs, a common denominator of all legal forms examined is their legal obligation to adhere persons from the target group as their members. In the case of SCE of integration, a percentage of members and of workers is obligatory to originate from the target group. Apart from that, the law neither incites (e.g. with financial motives) nor obligates an involvement of other parties. On the other hand, SCLL and SCI are subject to a multi-stakeholder structure of their membership and of the members of their Board of directors (target group and professionals), whereas women's agricultural cooperatives can only be formed as a single-stakeholder cooperative. Therefore, depending on legal form, the participatory nature of the WISEs varies between a single-stakeholder and a mandatory multi-stakeholder structure.

Based on the above, most EMES indicators that define a social enterprise (:a continuous activity producing goods and/or selling services, a significant level of economic risk, a minimum amount of paid work, a high degree of autonomy, a decision-making power not based on capital ownership, an explicit aim to benefit the community, an initiative launched by a group of citizens or civil society organization) are reflected in the provisions on the WISEs under study and they do not differ significantly between each other. However, this was not the case for the indicators of the profit distribution limitation and of the participatory nature of the WISE, in which the legal forms under study presented divergences, starting from profit distribution without any limitations to a profit non-distribution constrain and from a compulsory single-stakeholder structure to a multi-stakeholder structure of membership and of the members of the board of directors. 


\section{Supportive measures for the WISEs development}

The basic supportive measures prescribed by law for the above legal forms of WISEs are associated with public procurement, tax exceptions and the use of immovable or movable public property.

Concerning public procurement, ar. 20 L.4412/2016 prescribes for an open tender process, in which SCLL, SCE, as well as any legal entity may participate as long as $30 \%$ of its workers are disadvantaged or disabled. A much more specific measure is stipulated in ar. $110 \mathrm{~L} .4412 / 2016$, based on which public authorities may hold an open tender process for the provision of social services, in which only SCE have the right to participate.

Regarding the WISEs' tax treatment, the only WISEs exempted from an annual business tax are the SCEs, whereas the rest WISEs legal forms are obligated to pay such taxes. Such remark leads to the conclusion that SCEs enjoy a preferential tax treatment compared to the rest WISEs legal forms.

Concerning the use of public property (movable and immovable), ar. $5 \mathrm{~L}$. $4430 / 2016$ introduces relevant provisions for all legal entities that are recognized as SSE actors. The SCEs and the SCLL as ope legis SSE actors are subject to the latter provision, whereas the women's agricultural cooperatives and the SCI may benefit as long as they fulfil the criteria of ar. $3.2 \mathrm{~d} \mathrm{~L}$. 4430/2016 in order to be recognized as SSE actors.

Based on the above, the supportive measures prescribed by law are either generalized and focus on all SSE actors or specific for only particular types of WISEs, creating incentives for some legal forms and disincentives for others (Adam, Kornilakis and Kavoulakos 2018, 85).

\section{The thus far implementation and challenges}

In general, WISEs tend to occupy a small fraction of social economy (Davister, Defourny and Gregoir 2004, 3). In the Greek case, such hypothesis may also be re-affirmed, since they represent approximately $10,6 \%$ of the SSE sector (see Table $1)^{4}$. In the SCLL case, although the initial aim of establishing 58 SCLL (one in each mental health sector) was not realized to such extent (Adam 2014, 12), the number of the thus far SCLL registered to the social economy register- which is not mandatory for acquiring a legal personality- has increased to 27 (Social and Solidarity Econ- 
omy Registry). Based on previous research, their ability to reach their priority goal, by creating full- time, well-paid jobs for the target group has been under question (Adam 2014, 19-25). In some cases, there have been noted discrepancies between target group and professionals regarding the working conditions associated with payment, formal work contract and working hours (Adam 2014, 19-25). On the other hand, a number of SCLL has been able to sign public contracts with public authorities for service provision in areas such as catering, cleaning services or gardening. In addition, twelve years after the enactment of ar. 12 L. 2716/199 on SCLL, the Panhellenic Federation of SCLL Unions was found by 14 SCLL. The federation has been active since then in : a) promoting the interests of the SCLL, b) representing them to the Greek state, the national and international bodies and fora, c) shedding light to issues related to SCLL and providing information to its members-SCLL, d) co-operating with the Greek state and the EU and strive to address the issues that SCLL are facing 5 .

Concerning the SCE, only a few SCE of integration have been formed and these were mainly SCEs of integration of vulnerable groups, which indicates that the above legal form has not been implemented for the integration of able-bodied jobseekers that face serious issues in being (re)-integrated in the labour market. An overall remark for the majority of SCE is that they tend to have a limited economic activity, heavily relying on volunteer work and with a small contribution to the creation of well-paid, full time vacancies (Douvitsa 2016, 13-14; Special Secretary of Social and Solidarity Economy 2018, 102-110). The lack of social investment and adequate financial schemes tailored to their needs is usually mentioned as some of the challenges that they face. Also, the L. 4430/2016 leans towards overregulating the actors of SSE, in which SCEs of integration are included and thus dissuading interested parties from choosing it as the legal form for their initiative (Adam 2018, 239).

Regarding the women's agricultural cooperatives, it was noted that during the crisis years $1 / 3$ of them became inactive. The latter led the Ministry of Agriculture to undertake an investigation on the challenges and shortcomings that they were facing. Based on the Ministry's report findings, these cooperatives are very small-sized enterprises based on manual labor. They mainly produce in low quantities, which are sold locally. As a result, some of the most significant issues that they face are: the high costs of production, their inability to augment the quantities of produce, the difficulty in accessing the national and international markets and in investing in infrastructure and new technologies. In addition, a lack of a competitive profile of their products in the markets and an absence of a product certification (e.g. ISO) was 
also noted. One other issue that was equally highlighted was the absence of forming partnerships and of a co-ordinating body that would represent their interests (Tsiomidou 2016, 2-13).

Finally, the SCI are a newly prescribed by law legal form and therefore based on the data of the Department for Addressing Addictions of the Ministry of Health, there has been no record of SCI being established, thus far.

Table 1.

The legal forms with work integration as their explicit purpose

\begin{tabular}{|l|c|c|c|}
\hline WISEs Legal Forms & $\begin{array}{c}\text { Number of } \\
\text { registered } \\
\text { actors }\end{array}$ & $\begin{array}{c}\text { Number } \\
\text { of } \\
\text { members }\end{array}$ & $\begin{array}{c}\text { Number of workers } \\
\text { (Ergani database } \\
\text { 22/1/2020) }\end{array}$ \\
\hline 1. Social cooperatives of limited liability & 29 & N/A & 791 \\
\hline 2. Women's agricultural cooperatives & 129 & 2046 & 2046 \\
\hline $\begin{array}{l}\text { 3. Social cooperative enterprises of integration } \\
\text { of vulnerable groups }\end{array}$ & 23 & 261 & 58 \\
\hline $\begin{array}{l}\text { 4. Social cooperative enterprises of integration } \\
\text { of special groups }\end{array}$ & 7 & 58 & 3 \\
\hline 5. Social cooperatives of integration & 0 & 0 & 0 \\
\hline Total & 188 & 2365 & 2898 \\
\hline $\begin{array}{l}\text { Social and solidarity economy actors registered } \\
\text { in the Social Economy Registry }\end{array}$ & 1638 & 11649 & - \\
\hline
\end{tabular}

Source: Data retrieved by the Social Economy Registry of the Ministry of Labour, the Registry of Agricultural Cooperatives of the Ministry of Agriculture and Food and the Department for Addressing Addictions of the Ministry of Health.

Although the above remarks explicitly focus on the specific public policies on the WISEs, there is a broader need to build an overall supportive and enabling social and solidarity economy ecosystem, part of which are the WISEs, that would enable the effective development of all SSE actors and address the various challenges of work integration under the current conditions (Borzaga et al., 2017).

\section{Concluding remarks}

In Greece the emergence and development of WISEs may be divided into three time periods: a) the first period (1984-1998), during which the European public policies and funds incited the formation of early-stage cooperative initiatives, paving the way for the WISEs legal recognition, b) the second period (1999-2010), which 
is notable for the WISEs institutionalization in the mental health sector and c) the third period (2011-2019), during which WISEs became a vehicle for the integration of other groups of the population, the socio-economic and work inclusion of which was hindered by various factors.

Under the current context, the legislator introduces a number of specific legal forms under a cooperative structure that explicitly pursue the work integration of disadvantaged people. These specific legal forms are the social cooperatives of limited liability (ar. 12 L. 2716/1999), the women's agricultural cooperatives (L. 4384/2016), the social cooperative enterprises of integration of vulnerable groups and of special groups (L. 4430/2016) and the social cooperatives of integration (ar. 143 L. 4600/2019).

Based on the above, most EMES indicators that define a social enterprise are reflected in the provisions on the WISEs under study and such provisions do not differ significantly between each other. However, this was not the case for the indicators of the profit distribution limitation and of the participatory nature of the WISE, in which the legal forms under study presented divergences, starting from a profit distribution without limitations to a profit non-distribution constrain and from a compulsory single stakeholder structure to a multi-stakeholder structure of membership and of members of the board of directors.

Moreover, the public procurement, tax exception and the use of immovable or movable public property are among the fundamental supportive measures prescribed by law for the above legal forms for WISEs. These measures are either generalized and focused on all social and solidarity economy actors or specific for only particular types of WISEs, creating incentives for some legal forms and disincentives for others. Despite such measures, the WISEs face a number of challenges associated to their ability to create full- time, well-paid jobs for the target group, the difficulty in accessing the national and international markets and in investing in infrastructure and new technologies, among others.

To conclude, a dominance of the cooperative form for the WISEs is noted under the Greek context. The legislator imposes a percentage of members coming from the target group, perceiving in that way mutuality and solidarity as rather intertwined, since the WISEs' explicit aim of work integration of the disadvantaged people is mainly achieved by joining the cooperative. Although, the legislator prescribes for supportive measures for the WISEs, the thus far public policies have failed to further promote such a model of enterprise, which holds a marginal percentage of the social and solidarity economy sector. 


\section{Bibliography}

ADAM, S.: Social economy, work integration and social exclusion: the experience of

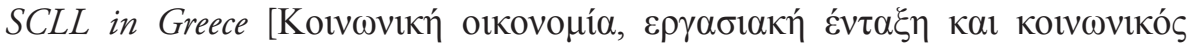

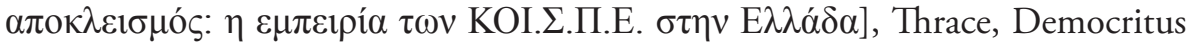
University of Thrace (PhD thesis), 2012.

- "Social and solidarity economy and the crisis: Challenges from the public policy perspective", Journal of Economics and Business, Vol. XXI, Nos 1-2, pp. 223-243.

- "Social exclusion and work integration: Social cooperatives for people with mental health problems in Greece". CIRIEC, Working Paper, ${ }^{\circ}{ }^{\text {. }}$ 08, Université de Liège, 2014.

ADAM, S., KORNILAKIS, A. \& KAVOULAKOS, K.I.: "The institutional framework of the social solidarity economy in Greece: The experience of the public consultation and a critical assessment of the law 4430/2016 [To $\theta \varepsilon \sigma \mu 1 \kappa o ́ ~ \pi \lambda \alpha i ́ \sigma ı$

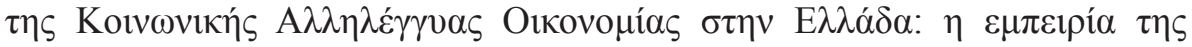

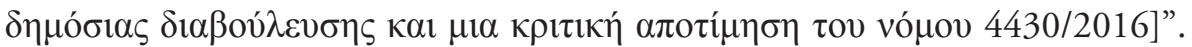
Thessaloniki, 2018.

- "Special Secretary of Social and Solidarity Economy", Annual Report, Ministry of Labour, Social Security and Social Solidarity, Athens, 2018.

BORZAGA, C., SALVATORI, G. \& BODINI, R.: Social and Solidarity Economy and the Future of Work, Geneva, International Labour Office, 2017.

DAVISTER, C., DEFOURNY, J. \& GREGOIRE, O.: "Work integration social enterprises in the European union: An overview of existing models", Working Paper, no. 04/04, EMES European Research Network, Belgium, 2004.

DEFOYRNY, J.: "Introduction: from third sector to social enterprise". In The emergence of social enterprise (Eds. BORZAGA, C. \& DEFOURNY, J.), London \& New York, 2001, pp. 1-28.

- "The EMES “ideal-type" social enterprise as a compass", 4th EMES International Research Conference on Social Enterprise, University of Liège, July 1-4 2013.

DEFOYRNY, J. \& NYSSENS, M.: "The EMES approach of social enterprise in a comparative perspective", Working Paper, n ${ }^{\circ}$ 12/03, EMES European Research Network, Belgium, 2012.

DOUVITSA, I.: "Greek cooperative legislation during the post-crisis years: Between companization and socialization", ICA Research International Conference, Almeria, Spain, 24-27 May 2016. 
PAPADOPOULOS, T. \& ROUMPAKIS, A.: "The Greek welfare state in the age of austerity: Anti-social policy and the politico-economic crisis". In Social Policy Review (KILKEY, M, RAMIA, G. \& FARNSWORTH, K.), Bristol, 2012, pp. 205-230.

- Explanatory memorandum of the draft law "Development and modernization of

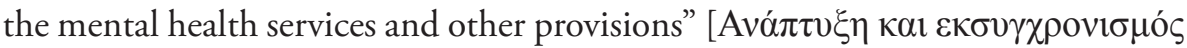

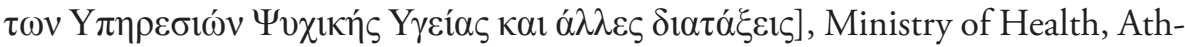
ens, 1999.

- Explanatory memorandum of the draft law "Modernisation and reform of the legal framework of private clinics, establishment of National Public Health Agency, establishment of the National Cancer Institute and other provisions"

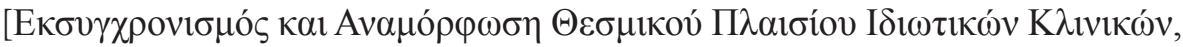

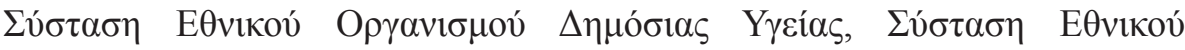

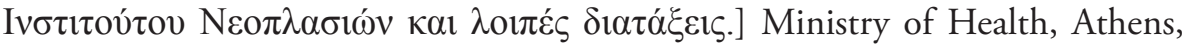
2019.

SPEARS, R. \& BIDET, E.: "Social enterprise for work integration in 12 European countries: A descriptive analysis", Annals of Public \& Cooperative Economics, Vol. 76, no ${ }^{\circ}$ 2, June, 2005, pp. 195-231.

STEFANAKIS, G.: Social cooperatives of limited liability (SCLL), a cooperative experiment in progress. The example of the SCLL of West Thessaloniki [Kouvovikoi

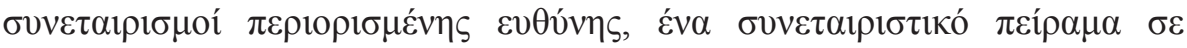

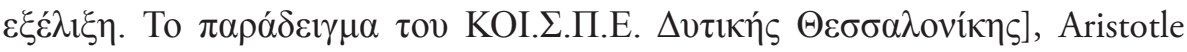
University of Thessaloniki, 2010.

TSIOMIDOU, E.: Women's agricultural cooperatives: An institution in need of propos-

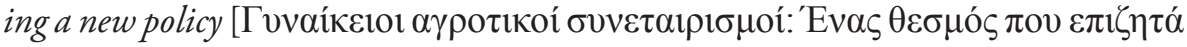

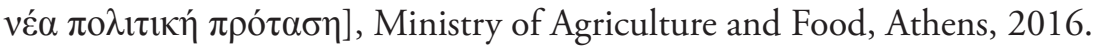

